\title{
RELIABILITY AND SAFETY OF STRUCTURAL ELEMENTS IN THE GIGACYCLE REGION OF LOADING
}

\begin{abstract}
The authors of this paper, based on their own results, discuss fatigue properties of low-alloyed fine-grained steel STRENX 700MC obtained in the ultra-high-cycle region (gigacycle fatigue) with regard to the reliability and safety of structural elements. According to obtained data it is obvious that fatigue strength continuously decreases with increasing number of cycles to failure (in a range from $N=10^{7}$ to $\mathrm{N}=10^{10} \mathrm{cycles}$ ). Fatigue limit $\sigma_{c}$ determined usually at $N=2 \times 10^{6} \div 10^{7}$ cycles does not meet the requirements of reliability and safety of structural elements. Design of structural elements which will be working in the ultra-high-cycle fatigue region requires complete information about fatigue behavior of used structural materials.
\end{abstract}

Keywords: Reliability, safety, steel STRENX 700MC, structural elements, gigacycle fatigue.

\section{Introduction}

Fatigue lifetime of structural elements has been investigated for more than 170 years. The strain or stress vs. number of cycles $\operatorname{plot}\left(\mathrm{S}-\mathrm{N}, \sigma_{\mathrm{a}}=\mathrm{f}(\mathrm{N})\right.$ dependence) including conventional fatigue limit $\sigma_{c}$ usually referred to $\mathrm{N}=2 \times 10^{6} \div 10^{7}$ cycles (valid for steels and cast irons) are the main parameters used for evaluation of fatigue properties of structural materials [1-3].

The modern industry has set the direction for the expansion of new design solutions for higher performance of industrial devices. The new design solutions are connected with the proper selection of materials for individual structural elements. This fact is crucial from the point of view of their reliability and safety and has also a huge contribution to increasing their service life. With the aim to prolong the service life of structural elements, the ultralong fatigue life $\left(10^{7}<\mathrm{N}<10^{10}\right.$ cycles $)$ has, therefore, been studied very intensively during recent years [1, 4 and 5]. This reality is emphasized by the fact that fatigue fractures are observed after billion cycles of loading and more.

The advanced structural materials are developed with the aim to prolong the service life of structural elements; the high-strength fine-grained steels are advisable materials applicable for the ultralong loading of these elements. Advanced steels often exhibit better mechanical properties compared to conventional steels [6] and, relevant to this fact, it is necessary to know also the fatigue characteristics of these advanced materials.
In this paper the authors provide their own results followed by a discussion about fatigue properties of low-alloyed fine-grained structural steel STRENX 700MC with reference to the reliability and safety of structural elements.

\section{Experimental part}

Experimental procedures, quantitative chemical analysis, metallographic analysis, tensile tests, fatigue tests and fractographic analysis were carried out for the low-alloyed fine-grained steel STRENX 700 MC. Chemical analysis was performed with the help of emission spectrometry on an ICP (JY 385) emission spectrometer using a fast recording system Image. A light metallographic microscope AXIO Imager A1m was used for metallography analysis. Tensile tests were carried out on a ZWICK Z050 testing machine at ambient temperature of $\mathrm{T}=20 \pm 5{ }^{\circ} \mathrm{C}$, with the loading range in interval $\mathrm{F}=0 \div 20 \mathrm{kN}$ and the strain velocity of $\dot{\varepsilon}_{\mathrm{m}}=10^{-3} \mathrm{~s}^{-1}$. Round cross-section specimens were used; the shape and dimensions of the test specimens met the requirements of EN 10002-1 standard (5 specimens were used). Fatigue tests were carried out at high-frequency sinusoidal cyclic tension-compression loading ( $\mathrm{f} \approx 20 \mathrm{kHz}, \mathrm{T}=20 \pm 5{ }^{\circ} \mathrm{C}$, $\mathrm{R}=-1$, cooled by distilled water with anticorrosive inhibitor) and with the use of high-frequency loading equipment KAUP-ZU Zilina. Smooth round bar specimens (14 pieces) with $4 \mathrm{~mm}$

\footnotetext{
* ${ }^{1,2}$ Frantisek Novy, ${ }^{3}$ Robert Ulewicz, ${ }^{1}$ Otakar Bokuvka, ${ }^{2}$ Libor Trsko, ${ }^{1}$ Jan Lago

${ }^{1}$ Department of Materials Engineering, Faculty of Mechanical Engineering, University of Zilina, Slovakia

${ }^{2}$ Research Centre of the University of Zilina, Slovakia

${ }^{3}$ Czestochowa University of Technology, Inst. of Production Technology, Czestochowa, Poland

E-mail: frantisek.novy@fstroj.uniza.sk
} 
diameter, ground and polished by metallographic procedures were used during the fatigue tests $[1,4$, and 7]. The investigated region of number of cycles ranged from $\mathrm{N} \approx 3 \times 10^{6}$ to $\mathrm{N}=10^{10}$ cycles of loading. The fractographic analyses of fatigue fracture surfaces were carried out using a scanning electron microscope TESCAN LMU II.

\section{Results and discussion}

The results of quantitative chemical analysis (chemical composition), metallographic analysis (microstructure), tensile tests (yield point in tension $\mathrm{R}_{\mathrm{e}}$, ultimate tensile strength $\mathrm{R}_{\mathrm{m}}$ ) and high-frequency fatigue tests (stress amplitude vs. number of cycles, $\sigma_{\mathrm{a}}-\mathrm{N}$ curve) are shown in Table 1 and Figs. 1 and 2 respectively. The experimental low-alloy steel STRENX 700MC had ultra-finegrained ferrite microstructure, see Fig. 1.

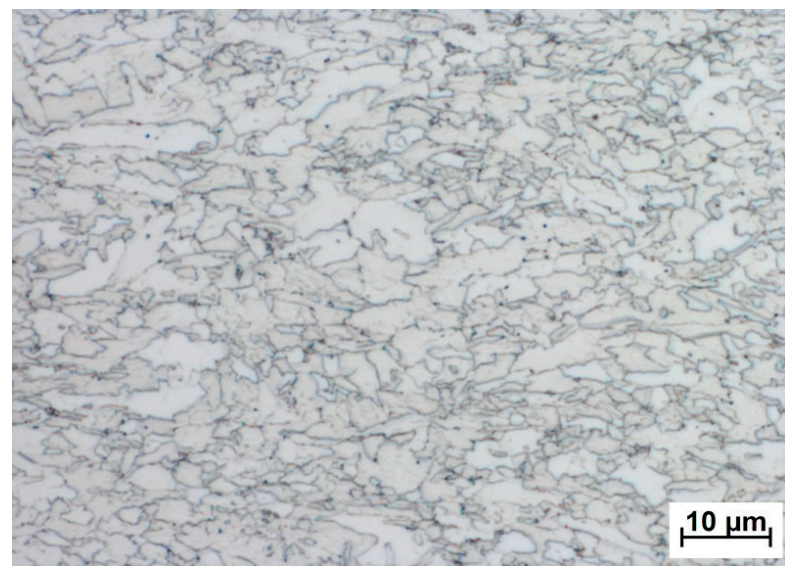

Fig. 1 Microstructure of tested steel STRENX 700MC

As is obvious from Fig. 2, the fatigue strength continuously decreases with increasing number of cycles to fracture in the whole tested region of cycles $\left(\Delta \sigma_{a}=160 \mathrm{MPa} ; \sigma_{a}=400 \mathrm{MPa}\right.$ at $\mathrm{N}=3 \times 10^{6}$ cycles vs. $\sigma_{\mathrm{a}}=240 \mathrm{MPa}$ at $\mathrm{N}=10^{10}$ cycles). This fact is in a good agreement with works [1, 4, 5, 8 and 9] where $\Delta \sigma$ is given from $\Delta \sigma_{\mathrm{a}}=20 \mathrm{MPa}$ to $\Delta \sigma_{\mathrm{a}}=200 \mathrm{MPa}$ whereas the higher values were observed at high-strength steels. The step-wise or duplex $\mathrm{S}-\mathrm{N}$ curve was not observed and it cannot be said that there is a constant amplitude of loading under which the structural element can stand an infinite number of cycles. The values of fatigue limit $\sigma_{c}$ obtained at $\mathrm{N}=2 \times 10^{6} \div 10^{7}$ cycles are overestimated and do not meet the demands of reliability and safety of structural elements [10]. These facts can be shown by comparison of $\mathrm{N}=10^{7}$ cycles vs. $\mathrm{N}=10^{10}$ cycles in the simplified Smith's diagram. The area of Smith's diagram for fine-grained steel STRENX 700MC drawn according to $\sigma_{\mathrm{a}}=384 \mathrm{MPa}$ obtained at $\mathrm{N}=10^{7}$ cycles is much bigger than the area of the Smith's diagram drawn according to $\sigma_{\mathrm{a}}=240 \mathrm{MPa}$ obtained at $\mathrm{N}=10^{10}$ cycles, Fig. 3 .

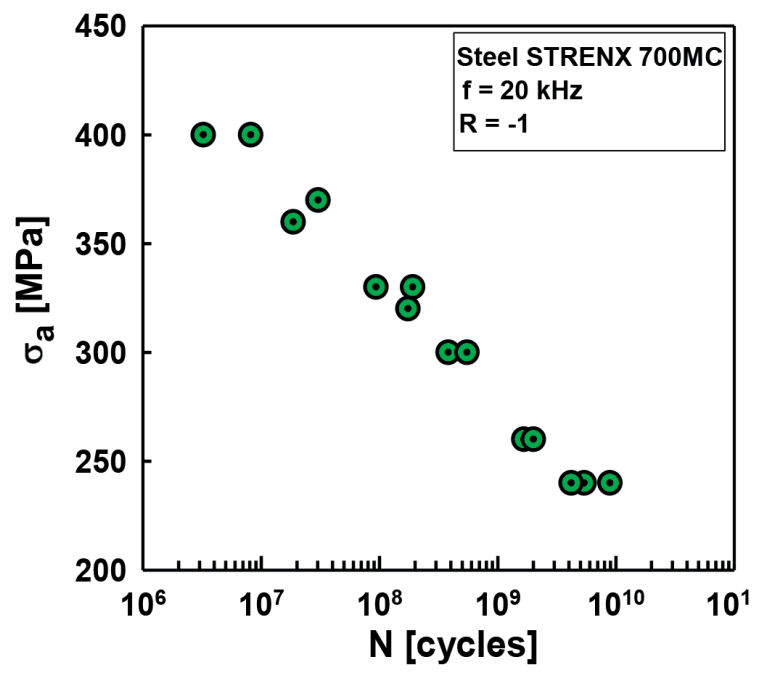

Fig. $2 \sigma_{a}-N$ curve of steel STRENX 700MC tested at high-frequency loading

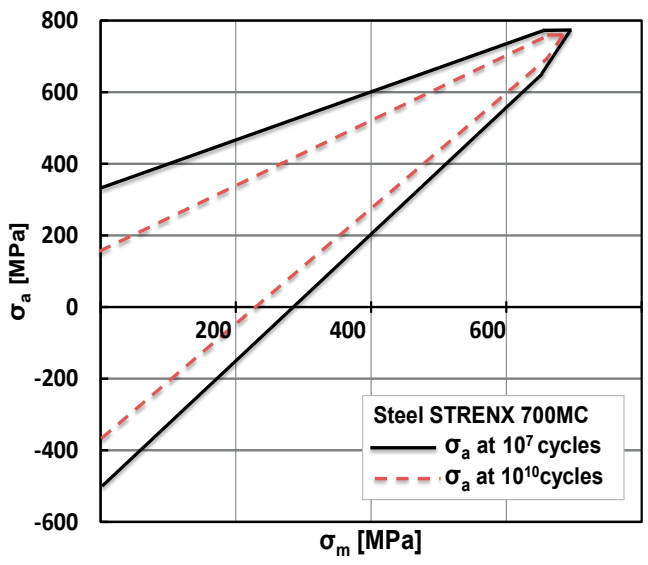

Fig. 3 Smith's diagram for steel STRENX 700MC drawn for $\sigma_{a}$ obtained at $N=10^{7}$ and $N=10^{10}$ cycles

The threshold value $\mathrm{K}_{\text {ath }}$ is very important information used by engineers for an optimal design of structural elements. $\mathrm{K}_{\mathrm{ath}}$ represents the resistance of steel against the fatigue crack

Chemical composition (in weight \%), Re and Rm of tested steel STRENX 700MC Table 1

\begin{tabular}{|c|c|c|c|c|c|c|c|c|c|c|c|}
\hline \multirow{2}{*}{ Element } & $\mathrm{C}$ & $\mathrm{Si}$ & $\mathrm{Mn}$ & $\mathrm{P}$ & $\mathrm{S}$ & $\mathrm{Cr}$ & $\mathrm{Ni}$ & $\mathrm{Mo}$ & $\mathrm{B}$ & $\mathrm{R}_{\mathrm{e}}(\mathrm{MPa})$ & $\mathrm{R}_{\mathrm{m}}(\mathrm{MPa})$ \\
\cline { 2 - 22 } & 0.20 & 0.39 & 0.80 & 0.005 & 0.005 & 0.45 & 0.05 & 0.01 & 0.001 & 796 & 849.4 \\
\hline
\end{tabular}


growth. It is determined according to interatomic distance (crystallography lattice parameter). If the crack length growth for one cycle is smaller than one interatomic distance, then cyclic loading has no degradation effect from the physical point of view (it does not cause a macroscopic growth of fatigue crack). In practice it means that for values $\mathrm{K}_{\mathrm{a}} \leq \mathrm{K}_{\text {ath }}$ cracks do not grow or the growth is extremely slow (slower than $\mathrm{da} / \mathrm{dN}=10^{-10} \mathrm{~m}_{\text {.cycle }}{ }^{-1}$ ) and it does not cause the breaking of steels by fatigue fracture for expected time of use [11 and 12]. The approximate threshold value $\mathrm{K}_{\text {ath }}$ of tested steel STRENX 700MC was calculated with following equation [13]

$$
K_{a t h}=-0.0052 \times R_{m}+8.5906 \quad\left(\mathrm{MPa}^{1 / 2}\right)
$$

in which $\mathrm{R}_{\mathrm{m}}$ is ultimate tensile strength (equation is valid in the region from $\mathrm{R}_{\mathrm{m}} \approx 360 \mathrm{MPa}$ to $\mathrm{R}_{\mathrm{m}} \approx 1040 \mathrm{MPa}$ and at highfrequency loading $)$. The obtained value $\left(\mathrm{K}_{\mathrm{ath}}=4.18 \mathrm{MPa} \cdot \mathrm{m}^{1 / 2}\right)$ is in an agreement with general conclusions published in works [1, 4, 7, 10 and 14] and with Lal's results which are valid for lowfrequency loading [15]. Consequently, approximate intrinsic crack lengths $\mathrm{a}_{01}$ were calculated for $\mathrm{N}=10^{7}$ cycles (at $\sigma_{\mathrm{a}}=384 \mathrm{MPa}$ ) and $\mathrm{a}_{02}$ for $\mathrm{N}=10^{10}$ cycles (at $\sigma_{\mathrm{a}}=240 \mathrm{MPa}$ ) of loading using the following equation [1, 4 and 11]

$$
K_{a t h}=\sigma_{a} \times\left(w \times \operatorname{tang} \frac{\pi \times a_{0}}{w}\right)^{1 / 2} \quad\left(\text { MPa.m }{ }^{1 / 2}\right)
$$

in which $\sigma_{\mathrm{a}}$ is the stress amplitude (MPa), $\mathrm{a}_{0}$ is the intrinsic crack length $(\mathrm{m})$ and $\mathrm{w}=0.016 \mathrm{~m}$ is the width of the used specimen [1 and 4]. The intrinsic crack lengths values were $\mathrm{a}_{01}=0.0377 \mathrm{~mm}$ and $\mathrm{a}_{02}=0.0965 \mathrm{~mm}$. The obtained results are in a good agreement with [14] where the author writes that $\mathrm{a}_{0} \leq 0.1 \div 1 \mathrm{~mm}$ in the case of low-strength steels and $\mathrm{a}_{0} \leq 10^{-2} \mathrm{~mm}$ in the case of high-strength

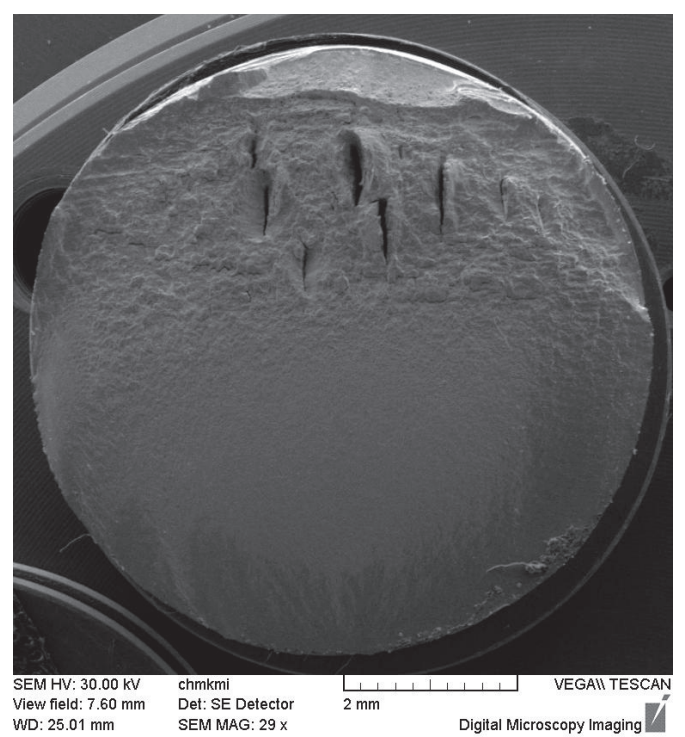

Fig. 5 Surface fatigue crack initiation, $\sigma_{a}=240 \mathrm{MPa}$ and at $\mathrm{N}=5.4 \times 10^{9} \mathrm{cycles}$

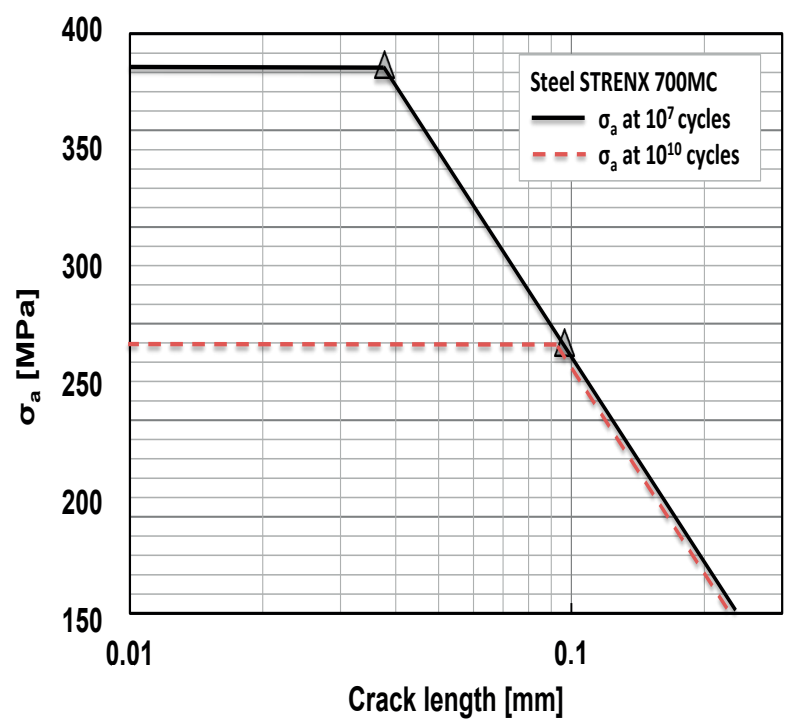

Fig. 4 Kitagawa-Takahashi's diagram for steel STRENX MC700 drawn for $N=10^{7}$ and $10^{10}$ cycles

steels. From Kitagawa-Takahashi's diagram [16] drawn for $\mathrm{N}=10^{7}$ and $10^{10}$ cycles, Fig. 4 , it is obvious that under cyclic loading with higher stress amplitude ( $\mathrm{K}$ - $\mathrm{T}$ diagram for $\mathrm{N}=10^{7}$ cycles, intrinsic crack length $\left.\mathrm{a}_{01}=0.0377\right)$, shorter cracks start to propagate under cyclic loading with lower stress amplitude $(\mathrm{K}-\mathrm{T}$ diagram for $\mathrm{N}=10^{10}$ cycles, intrinsic crack length $\mathrm{a}_{02}=0.0965 \mathrm{~mm}$ ). Also the boundary between short and long cracks is moving to bigger crack lengths with decrease of the loading amplitude [17].

Many years ago it was reported that fatigue cracks initiation occurred from small defects on the surface at high stress amplitude levels and low number of cycles. Only in the last

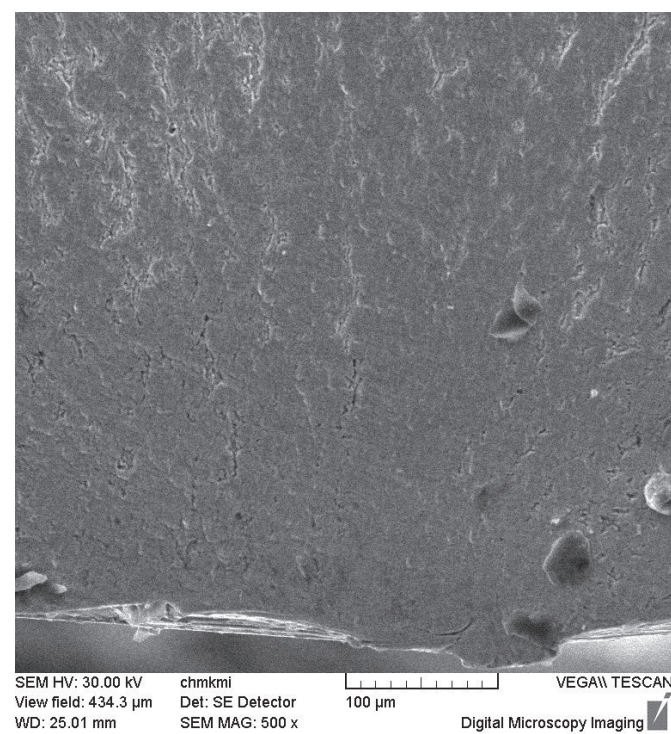

Fig. 6 Surface fatigue crack initiation, $\sigma_{a}=240 \mathrm{MPa}$ and at $\mathrm{N}=5.4 \times 10^{9} \mathrm{cycles}$ 
decades it was reported that fatigue cracks start in the subsurface zone at low stress amplitude level and ultra-high number of cycles. Subsurface fatigue crack initiation in the ultra-high number of cycles region is a microstructure related phenomenon which determines the fatigue lifetime, and is associated with structural heterogeneities such as inclusions, microphores, microshrinkages, large or very small grains region, etc. [1, 4, 10, 14 and 17 -22]. The microstructure image of tested steel STRENX 700MC revealed sparse titanium nitride particles with a regular geometric shape as well as few inclusions in the form of black manganese sulphide particles. Despite of this fact only surface crack initiation was observed, Figs. 5 and 6 . As the result of polished surface of the specimen, with the purpose to eliminate the notch effect after machining, it was possible that the surface initiated cracks could start only from the surface concentrators in the surface relief, which was created during the cyclic loading. During the cyclic loading there are microstructural changes observed in the material. The number and the configuration of structural defects are changing, whereby the most important change is the creation of the dislocation structure. The characteristics of the dislocation structure depend on the micro-plastic deformation which depends on the applied stress amplitude. At the same time, the cyclic micro-plastic deformation is localized into slip bands. In the places where slip bands come up to the surface, intrusions and extrusions are generated and create the surface relief; intrusions are strong stress concentrators and the surface fatigue cracks initiation then starts in the roots of intrusions [1, 3, 4, 10, 11 and $16-23]$.

\section{Conclusions}

With reference to the experimental results the following can be summed up:

- in the low-alloyed fine-grained steel STRENX 700MC a continuous decrease of fatigue strength in dependence on the number of loading cycles to fracture is observable in the gigacycle region of loading;

- the values of fatigue limit $\sigma_{c}$ obtained at $\mathrm{N}=2 \times 10^{6} \div 10^{7}$ cycles are overestimated and do not meet the demands of reliability and safety of structural elements;

- the safety area of Smith's and Kitagawa-Takahashi's diagrams is much smaller at $\mathrm{N}=10^{10}$ cycles than at $\mathrm{N}=10^{7}$ cycles;

- the intrinsic crack length decreases with the increase of loading amplitude;

- only surface fatigue crack initiation was observed;

- these facts must be taken into consideration with reference to reliability and safety when designing structural elements.

\section{Acknowledgements}

The research was supported by Scientific Grant Agency of Ministry of Education, Science and Sport of Slovak Republic and Slovak Academy of Sciences, grant VEGA No. 1/0123/15 and 1/0720/14, by the project APVV-14-0096 and project "Research Centre of the University of Zilina”, ITMS 26220220183.

\section{References}

[1] BoKUVKA, O., NiCOletTo, G., GUAGliano, M., KUNZ, L., PAlCEK, P., NOVY, F., CHALUPOVA, M.: Fatigue of Materials at Low and High-frequency Loading. EDIS ZU Zilina, 2015.

[2] HURTAlOVA, L., TILlOVA, E., CHALUPOVA, M.: Key Eng. Mat., vol. 592-593, p. 433.

[3] KUNZ, L.: Experimental Determination of Fatigue Characteristics of Materials (in Czech). EDIS ZU Zilina, 2003.

[4] BOKUVKA, O., NICOLETTO, G., KUNZ, L., PALCEK, P., CHALUPOVA, M.: Low and High Frequency Fatigue Testing. EDIS ZU Zilina, 2002.

[5] BATHIAS, C., PARIS, P. C.: Gigacycle Fatigue in Mechanical Practice. M. Dekker : N. York, 2005.

[6] KUZLIAK, R., KAWALLA, R., WAENGLER, S.: Arch. of Civil and Mech. Engng., vol. 8, No. 2, 2008, p. 103.

[7] PUSKAR, A.: Highfrequency Fatigue of Materials (in Slovak). EDIS ZU Zilina, 1997.

[8] ULEWICZ, R., MAZUR, M.: Prod. Engng. Arch., No. 1, 2013, p. 32.

[9] SZATANIAK, P.: Fatigue Properties of Fine-grained Steels. PhD. Thesis, ZU Zilina, 2016.

[10] NOVY, F., BOKUVKA, O., TRSKO, L., CHALUPOVA, M.: Annals of Fac. Eng. Huneodora - Int. J. of Engng., vol. 10, No. 2, 2012, p. 231.

[11] KLESNIL M., LUKAS P.: Fatigue of Metal Materials at Mechanical Loading (in Czech). ACADEMIA Praha, 1975.

[12] TRSKO, L., NOVY, F., BOKUVKA, O.: Dynamics Strength and Fatigue Lifetime. EDIS ZU Zilina, 2013.

[13] RUZICKOVA, M., BOKUVKA, O., PALCEK, P., CHALUPOVA, M.: Materials Engng., vol. 6, No. 15, p. 19.

[14] RITCHIE, R.O.: Application of Fracture Mechanics to Fatigue Crack Propagation. University of California, 1981.

[15] LAL, D. N.: Fat. Frac. Engng. Mater. Struct., vol. 15, No. 12, 1992, p. 1199.

[16] KITAGAWA, H., TAKAHASHI, S.: Proc. of the $2^{\text {nd }}$ Int. Conf. on Mechanical Behavior of Materials, ASM, 1976, p. 627. 
[17] NOVY, F., BOKUVKA, O., MINTACH, R., TRSKO, L.: Perner's Contacts, vol. 6, No. 2, 2011, p. 131.

[18] MURAKAMI, Y., NOMOTO, T., UEDA, T.: Fatigue Fract. Engng. Struct., vol. 22, 1999, p. 581.

[19] MURAKAMI, Y., NOMOTO, T., UEDA, T.: Fatigue Fract. Engng. Struct., vol. 23, 2000, p. 903.

[20] MURAKAMI, Y.: Metal Fatigue: Effects of Small Defects and Nonmetalic Inclusions, $1^{\text {st }}$ ed., Oxford : Elsevier Ltd., 2002.

[21] SZATANIAK, P., MAZUR, M., ULEWICZ, R., NOVY, F.: Communications - Scientific Letters of the University of Zilina, vol. 18, No. 1, 2016, p. 89.

[22] MURAKAMI, Y., NOMOTO, T., UEDA, T.: Fatigue Fract. Engng. Struct., vol. 23, 2000, p. 893.

[23] PUSKAR, A., HAZLINGER, M.: Failure and Fractures of Components (in Slovak), EDIS : ZU Zilina, 2000. 